\title{
UPAYA MENINGKATKAN PEMAHAMAN TENTANG PERANAN INFORMASI DALAM KUALITAS PRODUK DAN JASA PADA MATA KULIAH SISTEM INFORMASI MANAJEMEN MELALUI PENERAPAN METODE JIGSAW BAGI MAHASISWA POLITEKNIK UBAYA PRODI SEKRETARI ANGKATAN 2014 DAN 2015
}

\author{
Slamet Wahyudi* \\ slamet.wahyudi@staff.Ubaya.ac.id
}

\section{Abstract}

In order to improve a classroom engagement in learning one specific lesson, for instance, in Management Information System (MIS) subject, certainly there is an extra effort need to be done. MIS originally is a quite technical lesson that requires adequate prior knowledge on Management and Information system. Clearly, MIS is something new for secretary study program students. As a lecturer, we need to shift from becoming the centre of learning rather than to lead students to become more active in the learning process (student - centered learning). In relation to that, a classroom action research (CAR) is needed urgently to help both lecturer and students running the class effectively. This time, the researcher tries to implement a Jigsaw learning type throughout two stages and phases. Hopefully, all students who learn one of MIS chapter which is about 'The role of Information to increase product and service quality' could understand the topic better than before using Jigsaw. Then, finally all secretary students who enrolled in this class could achieve a good mark in the final exam.

Keywords: Management Information System (MIS), Secretary StudyProgram Students, Classroom Action Research (CAR), Jigsaw, Product and Service quality.

\section{Pendahuluan}

\section{Latar Belakang Masalah}

Penerapan Sistem Informasi Manajemen (SIM) menjadi sebuah kebutuhan yang integral bagi sebuah perusahaan, dengan pemahaman SIM yang baik akan dapat membantu perusahaan memiliki sebuah keunggulan kompetitif di era digital seperti sekarang ini. Kebanyakan mahasiswa menganggap bahwa SIM sebagai mata kuliah yang sulit dan tidak terlalu menarik untuk dipelajari. Padahal SIM merupakan ilmu manajemen yang banyak berguna dalam

* Dosen Program Studi D3 Sekretari, Politeknik Ubaya, Surabaya 
dunia kerja nyata khususnya bagi sekretaris yang diharapkan paham tentang seluk beluk perkantoran. Oleh karena itu SIM perlu dipelajari oleh setiap mahasiswa Program Studi Sekretari Politeknik Ubaya.

Berdasarkan hasil pengamatan yang dilakukan di perkuliahan mata kuliah SIM, proses perkuliahaan yang diterapkan adalah metode kuliah yang berpusat pada dosen (teacher oriented). Mahasiswa tidak aktif dalam kegiatan perkuliahan. Hal ini bisa dilihat dari minat belajar dan mengerjakan tugas di kelas. Karena selama perkuliahan dosen lebih sering berceramah tentang materi, sehingga aktivitas yang dilakukan mahasiswa di dalam kelas biasanya hanya mendengar ceramah dan sesekali mencatat. Mahasiswa Prodi Sekretari angkatan 2014 dan 2015 tidak berminat bertanya atau menyampaikan opini. Selain itu, diskusi antar-kelompok di kelas jarang dilakukan, sehingga interaksi dan komunikasi dua arah antara mahasiswa dengan rekan lainnya maupun dengan dosen SIM belum terbangun selama proses perkuliahan SIM.

Melalui penerapan model pembelajaran Jigsaw diharapkan dapat meningkatkan pemahahaman mahasiswa tentang peranan informasi dalam kualitas produk dan jasa. Berdasarkan uraian di atas maka peneliti mengajukan proposal penelitian dengan judul "Upaya Meningkatkan Pemahaman tentang Peranan Informasi dalam Kualitas Produk dan Jasa pada Mata kuliah Sistem Informasi Manajemen melalui Penerapan Metode Jigsaw bagi Mahasiswa Politeknik Ubaya Surabaya Program Studi Sekretari Angkatan 2014 dan 2015". Penelitian ini perlu dan mendesak dilakukan untuk mengetahui apakah penerapan metode Jigsaw mampu meningkatkan pemahaman materi mahasiswa sekretari khususnya.

Proses pembelajaran juga memerlukan perencanaan yang baik (Djoehaeni, 2009). Dengan penyusunan strategi-strategi yang disiapkan sebelumnya, maka akan didapatkan hasil yang lebih optimal, daripada terlaksana pembelajaran tanpa rencana dan strategi yang tepat (Ali, 1992).

\section{Identifikasi Masalah dan Alternatif Pemecahan Masalah}

Dalam proses perkuliahan mata kuliah SIM pada materi peranan informasi dalam kualitas produk dan jasa mahasiswa Prodi Sekretari Politeknik UBAYA angkatan 2014 dan 2015 mengalami kesulitan dalam menjawab pertanyaan dosen secara langsung maupun pertanyaan dalam bentuk tertulis.

Salah satu model pembelajaran yang paling cocok dalam upaya mendorong keaktifan, kemandirian dan tanggung jawab yang pada akhirnya mampu meningkatkan pemahaman materi secara lebih baik adalah dengan penerapan metode Jigsaw.

\section{Pembatasan Masalah}

Berdasarkan pemaparan latar belakang di atas, penelitian tindakan kelas ini hanya akan membahas masalah upaya meningkatkan pemahaman mahasiswa Prodi Sekretari Politeknik UBAYA angkatan 2014 dan 2015 melalui penerapan model pembelajaran inovatif Jigsaw. Dalam penelitian tindakan kelas ini sebagai indikator keberhasilan adalah meningkatnya pemahaman mahasiswa dilihat dari proses perkuliahaan selama diberikan tindakan dan semakin meningkat secara signifikan hasil tes akhir mahasiswa dengan hasil pre test.

\section{Rumusan Masalah}

Berdasarkan pembatasan masalah diatas, maka rumusan masalah penelitian ini yaitu, apakah penerapan Metode Jigsaw mampu meningkatkan pemahaman mahasiswa Prodi Sekretari Politeknik UBAYA angkatan 2014 dan 2015 tentang materi Peranan Informasi dalam Produk dan Jasa. 


\section{Tujuan Penelitian}

Tujuan penelitian ini adalah mendeskripsikan/membuktikan apakah penerapan metode Jigsaw mampu meningkatkan pemahaman mahasiswa Prodi Sekretari Politeknik Ubaya angkatan 2014 dan 2015 tentang materi peranan informasi dalam produk dan jasa.

\section{Manfaat Penelitian}

Hasil penelitian tindakan kelas ini diharapkan mampu memberikan kontribusi dan manfaat nyata:

(a) sebagai bahan pertimbangan bagi dosen dalam memilih model pembelajaran dengan tujuan agar dapat meningkatkan kemampuan pemahaman materi mahasiswa akan materi yang sulit dipahami;

(b) sebagai penyegaran cara belajar aktif bagi mahasiswa sekretari dalam proses meningkatkan pemahaman materi Peranan Informasi dalam Produk dan Jasa mata kuliah SIM.

(c) Sebagai pengembangan pengetahuan bagi peneliti khususnya tentang penelitian dalam pembelajaran SIM.

\section{Kajian Teori dan Hipotesis}

\section{Kajian Teori}

\section{Kosep Dasar Belajar}

Seseorang yang membaca buku terusmenerus belum tentu bisa dikategorikan sebagai seseorang yang belajar. Karena seseorang baru disebut sedang belajar jika orang tersebut mampu melakukan atau memiliki keahlian akan sesuatu hal melalui tahapan pelatihan sehingga orang tersebut berubah menjadi lebih baik (Rianto, 2012). Jadi, orang yang belajar akan sesuatu hal sudah seharusnya memiliki kemampuan yang lebih baik daripada orang yang hanya sekedar membaca buku tanpa ada proses perubahan dalam dirinya untuk menjadi lebih menguasai.

Para ahli berhasil mendefinisikan makna belajar berdasarkan sudut pandang mereka masing-masing terhadap suatu hal. Menurut Winkel (1996), belajar merupakan sebuah kegiatan mental dan fisik yang berlangsung terus-menerus serta aktif dipengaruhi oleh lingkungan yang bersangkutan berada. Belajar yang baik mampu menambah pengetahuan dan pemahaman serta keterampilan pada saat yang bersamaan, sehingga orang yang belajar akan mengingat apa yang dipelajari dalam waktu yang relatif lama.

Definisi belajar yang lain diutarakan oleh Degeng (1997) yang menyebutkan bahwa pada saat orang belajar maka akan terjadi proses penggabungan antara pengetahuan yang sudah secara otodidak dimiliki sebelumnya dengan pengetahuan yang baru diperolehnya. Sehingga dengan belajar seharusnya mahasiswa aktif untuk mengaitkan pengetahuan apa saja yang mereka kuasai dan terkait dengan materi yang diajarkan oleh jajaran dosen pengajar di perkuliahan. Belajar melibatkan lebih banyak faktor seperti persepsi, kemampuan, emosional, dan proses penalaran (1997). Faktor tersebut penting untuk diperhatikan bagi dosen maupun mahasiswa sehingga tujuan dari belajar itu sendiri bisa dicapai secara utuh dan berkesinambungan.

\section{Pembelajaran}

Dalam sistem pendidikan pembelajaran merupakan salah satu dari lima komponen lainnya, seperti evaluasi, konseling, administrasi, serta kurikulum (Yamin, 2013). Sedangkan menurut pendapat pakar pendidikan Yusuf Hadi Miarso (2004), pembelajaran merupakan sebuah proses yang sengaja dirancang sedemikian rupa, memiliki tujuan tertentu yang ingin dicapai, terstruktur, dan terkendali sehingga menyebabkan orang lain belajar. Dengan mengikuti pembelajaran diharapkan hasilnya nyata dan bisa ditransfer ke orang lain.

Dengan demikian sudah semestinya pembelajaran yang dirancang oleh pihak pe- 
nyelenggara pendidikan tinggi mampu dilakukan secara baik bukan saja oleh peserta didik dalam ini mahasiswa namun terlebih juga bisa diaplikasikan dengan baik oleh pendidik atau dosen pengampu mata kuliah. Seperti yang dikemukakan oleh Walter dan Reiser (1996), dapat membantu orang lain yang belajar mendapatkan keterampilan, kemampuan, pengetahuan, dan sikap yang benar dalam belajar, serta mereka antusias selama proses pembelajaran berlangsung.

\section{Strategi Pembelajaran Kooperatif}

Pembelajaran tidak harus selalu mengandalkan dosen sebagai sumber informasi. Dosen selama ini lebih sering menjadi pusat dari kegiatan pembelajaran, padahal pembelajaran tersebut terkait dengan peserta kuliah yang memang datang ke kelas seharusnya untuk belajar sebuah pengetahuan baru. Menurut Trianto (2007), sistem pembelajaran yang lebih bisa menggugah mahasiswa belajar adalah sistem pembelajaran kooperatif, di mana secara hakikat melibatkan mahasiswa secara langsung dalam pemecahan masalah yang ditemui, mahasiswa terkadang lebih mudah memahami sebuah materi kuliah jika teman sejawatnya yang menjelaskan melalui sebuah diskusi kelompok.

Dalam proses pembelajaran kooperatif, mahasiswa belajar bersama dalam sebuah kelompok kecil yang dibentuk oleh dosen, biasanya terdiri atas 4-6 mahasiswa. Dalam kelompok heterogen tersebut dipilih mahasiswa yang memiliki kemampuan, suku atau ras yang berbeda namun saling membantu satu sama lain (Trianto, 2007).

Menurut Killen (1996) dikutip dalam Trianto (2007), pembelajaran kooperatif memiliki karakter di antaranya sebagai berikut: terdapat adanya ketergantungan satu sama lain dalam kelompok, peserta saling memotivasi dan membantu rekan lainnya. Selain itu bisa diketahui anggota yang mana yang memiliki kemampuan relatif kurang dan siapa anggota kelompok yang menguasai materi dengan baik, sehingga bisa saling membantu dengan menggunakan bahasa yang mudah dipahami. Karakter selanjutnya adalah ketua kelompok dipilih secara demokratis dan bergantian sehingga semua memiliki kesempatan yang sama. Dalam hal pembelajaran kooperatif peran dosen adalah sebagai sebagai pemantau aktif, melakukan observasi, dan jika diperlukan ikut intervensi jika ada hal yang sulit dipecahkan kelompok. Karakter lainnya adalah pada titik beratnya bukan hanya peningkatan pemahaman namun juga adanya hubungan interpersonal yang lebih erat antar-anggota kelompok.

Dari uraian di atas, mata kuliah Sistem Informasi Manajemen sangat memungkinkan untuk menggunakan strategi pembelajaran kooperatif karena mahasiswa Sekretari 2014 dan 2015 diyakini lebih bisa memahami materi jika mereka bisa terlibat secara langsung dalam proses belajar.

\section{Pembelajaran Kooperatif Tipe Jigsaw}

Jigsaw dikembangkan di Universitas Texas oleh Elliot Aronson serta diteliti lebih lanjut dan dipraktikkan di Universitas John Hopkins oleh Slavin beserta rekan (Arends, 2004). Teknik ini cocok untuk digunakan dalam pembelajaran tentang materi membaca, menulis, bicara maupun mendengarkan (Yamin, 2013).

Dalam penerapan metode Jigsaw setiap anggota kelompok dibagi materi yang harus mereka pelajari dan kuasai sehingga menjadikan mereka ahli dalam hal tersebut. Selanjutnya anggota yang ahli tersebut bertemu dengan anggota ahli dari kelompok lain untuk membahas bidang keahlian mereka tersebut. Setelah selesai dari tugas diskusi para ahli, mereka kembali ke kelompok masing-masing dan mempunyai tugas untuk menjelaskan kepada anggota kelompok tentang materi yang mereka kuasai. Begitu seterusnya secara bergantian, hingga semua paham akan materi yang dipelajari. Pada 
tahap akhir anggota kelompok akan diuji secara individual mengenai semua materi untuk mendapatkan poin atau skor bagi kelompoknya (Yamin, 2013).

Inti dari pembelajaran kooperatif Jigsaw ini adalah aplikasi kerja sama tim yang solid, melalui cara belajar kelompok yang heterogen di mana masing-masing anggota kelompok bertanggung jawab untuk menjadi ahli atas satu bahan materi kuliah (Yamin, 2013).

Pada model pembelajaran Jigsaw ini kelompok yang ada dibedakan menjadi dua kelompok, yaitu kelompok asal dan kelompok ahli. Kelompok asal adalah kelompok yang menjadi induk anggota dengan latar belakang yang beragam, serta keahlian yang berbeda pula. Sedangkan kelompok ahli adalah kelompok para pakar dari kelompok asal yang ditugaskan untuk berdiskusi dan mendalami materi terkait perkuliahan.

Menurut Aronson dan rekan dalam Riyanto (2012), langkah-langkah penerapan metode Jigsaw bisa dibagi menjadi beberapa tahap berikut di antaranya adalah: Pertama, dibentuk kelompok belajar yang anggotanya disesuaikan dengan jumlah mahasiswa. Kedua, setiap mahasiswa yang menjadi anggota kelompok dibagikan materi yang berbeda. Langkah ketiga, dosen membagikan handout materi yang berbeda. Sementara itu kelompok lainnya juga mendapat tugas dan materi yang sama. Selanjutnya, mahasiswa yang menguasai materi A misalnya akan berkelompok lagi dengan mahasiswa dari kelompok lainnya yang menguasai materi A juga. Setelah selesai maka mahasiswa yang ahli materi A bertanggung jawab menyampaikan materi tersebut ke anggota

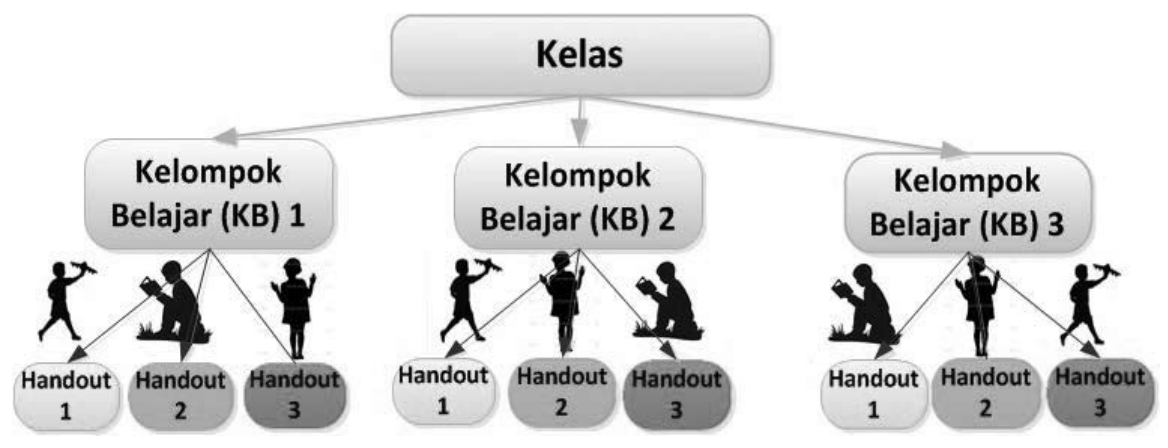

Gambar 1. Ilustrasi Kelompok Asal Jigsaw (gurupembaharu.com, 2014)

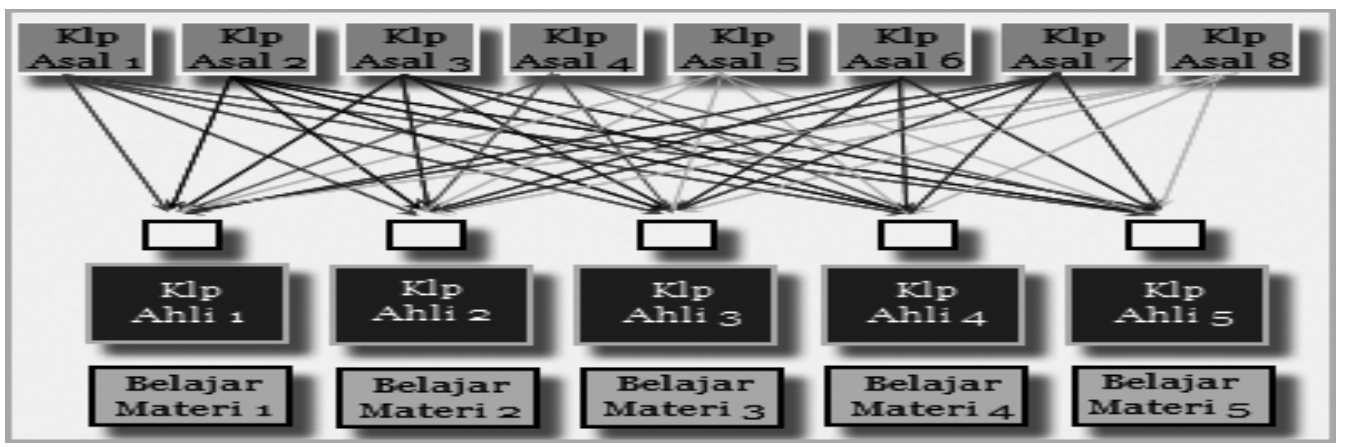

Gambar 2. Pembentukan Kelompok Jigsaw (modifikasi dari Tugino, 2013) 
kelompok asal yang lain. Begitu seterusnya hingga materi yang diajarkan selesai didiskusikan. Setelah selesai tiap tim ahli mempresentasikan materi mereka, dan dosen bisa melakukan tes atau kuis sebagai evaluasi sejauh mana pemahaman mereka terhadap materi tersebut.

\section{Kerangka Berpikir}

Pemaparan di atas jika dimasukkan dalam sebuah kerangka berbentuk tabel adalah seperti yang bisa dibaca pada Tabel 1 .

\section{Hipotesis Tindakan}

Atas dasar teori yang dipaparkan di atas, dalam penelitian ini dirumuskan hipotesis tindakan, yakni penerapan metode Jigsaw mampu meningkatkan pemahaman mahasiswa Prodi Sekretari Politeknik Ubaya angkatan 2014 dan 2015 tentang materi Peranan Informasi dalam Produk dan Jasa.

\section{Indikator Keberhasilan}

Indikator keberhasilan penelitian ini adalah meningkatnya pemahaman mahasiswa Prodi Sekretari angkatan 2014 dan 2015 tentang materi Peranan Informasi dalam Produk dan Jasa. Peningkatan pemahaman materi tersebut pada mahasiswa dilihat dari selama proses kegiatan perkuliahan berlangsung mahasiswa antusias berdiskusi

Tabel 1. Urutan Pelaksanaan Penelitian Tindakan Kelas (PTK).

\begin{tabular}{|c|c|c|}
\hline Keadaan Awal & $\begin{array}{l}\text { Mahasiswa Sekretari } 2014 \text { dan } \\
2015 \text { tidak memiliki kemauan } \\
\text { mempelajari materi SIM khu- } \\
\text { susnya materi Peranan infor- } \\
\text { masi dalam produk dan jasa. } \\
\text { Mahasiswa tergantung sepe- } \\
\text { nuhnya pada dosen yang me- } \\
\text { ngajar, tidak ada interaksi ak- } \\
\text { tif dari mahasiswa di kelas }\end{array}$ & Evaluasi Awal \\
\hline Tindakan & $\begin{array}{l}\text { Penjelasan tentang metode } \\
\text { pembelajaran kooperatif Jig- } \\
\text { saw; } \\
\text { Penerapan metode Jigsaw di } \\
\text { kelas SIM; } \\
\text { Refleksi dari hasil penerapan } \\
\text { metode Jigsaw bagi maha- } \\
\text { siswa sekretari } 2014 \text { dan } 2015\end{array}$ & Evaluasi Pengaruh Tindakan \\
\hline Hasil Akhir & $\begin{array}{l}\text { Metode Jigsaw mampu me- } \\
\text { ningkatkan pemahaman Ma- } \\
\text { hasiswa Sekretari } 2014 \text { dan } \\
2015 \text { tentang materi Peranan } \\
\text { Informasi dalam produk dan } \\
\text { jasa }\end{array}$ & Evaluasi Akhir \\
\hline
\end{tabular}


dan bertanya mengenai materi tersebut. Selain itu, peningkatan pemahaman materi SIM tersebut bisa diperoleh dari perbandingan hasil pre test dan post test mahasiswa sebelum penerapan model Jigsaw dan setelah model Jigsaw diterapkan. Jika terjadi peningkatan yang signifikan dari 60 ke 90 berarti metode Jigsaw berhasil membantu meningkatkan pemahaman mahasiswa akan materi Peranan Informasi dalam Produk dan Jasa.

\section{Metodologi Penelitian}

\section{Metode Penelitian}

Penelitian ini dilakukan menggunakan metode Classroom Action Research atau lebih dikenal dengan istilah metode Penelitian Tindakan Kelas (PTK). Penelitian ini dilakukan secara sendiri namun tetap bekerja sama dengan pengajar mata kuliah Sistem Informasi Manajemen (SIM) semester genap. Tahapan-tahapan yang ditempuh dalam penelitian ini adalah: (a) perencanaan, (b) Pelaksanaan, (c) Pengamatan, dan (d) Refleksi (Yudhistira, 2013).

Seperti dijelaskan oleh Yudhistira (2013), penggunaan model PTK dalam penelitian ini karena PTK memiliki manfaat di antaranya adalah: membiasakan diri dengan kegiatan menulis karya ilmiah, memberikan inovasi dalam pembelajaran, mampu mengembangkan SAP yang dipakai, dan yang terakhir meningkatkan kualitas dosen sesuai dengan tridarma perguruan tinggi.

\section{Prosedur Penelitian}

Seperti halnya karakter khusus dalam penelitian PTK yang dilakukan secara berkesinambungan melalui siklus yang berulang, maka penelitian ini melalui langkahlangkah sebagai berikut di antaranya: (a) perencanaan, (b) pelaksanaan/pengamatan, dan (c) refleksi. Tahapan penelitian ini tampak pada Gambar 3 di bawah ini.

Penelitian tindakan kelas ini melalui siklus yang diharapkan bisa menghasilkan temuan yang paling tepat untuk dipakai peneliti.

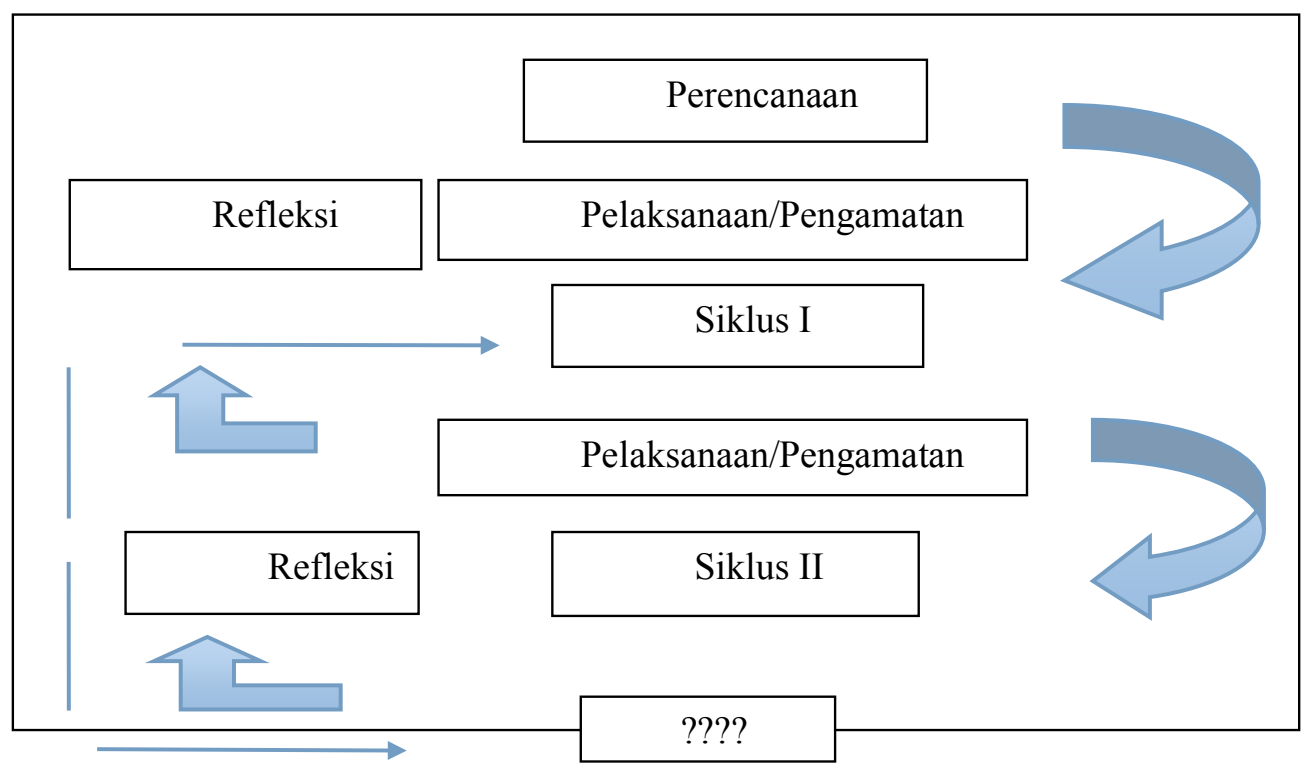

Gambar 3. Siklus Penelitian. 


\section{Siklus I}

a. Perencanaan

Pada tahap ini kegiatan penelitian di antaranya adalah melakukan kerja sama dengan cara berdiskusi dengan tim peneliti untuk membangun kesamaan ide tentang masalah di kelas dan bisa dikembangkan untuk menyusun kegiatan demi perbaikan perkuliahan. Kegiatan di tahap perencanaan ini meliputi proses identifikasi, analisis, perumusan masalah, dan merumuskan tindakan berupa hipotesis tindakan.

b. Pelaksanaan

Pada tahap ini beberapa proses penelitian yang dilakukan adalah mempersiapkan materi dan perangkat pembelajaran seperti SAP, GBPP, dan perangkat lainnya. Fasilitas pendukung implementasi metode Jigsaw juga disiapkan seperti handout materi yang telah dibagi sesuai bab terkait peranan informasi dalam produk dan jasa. Sebelum pelaksanaan ada baiknya untuk melakukan percobaan dulu seperti simulasi penerapan metode Jigsaw agar kemungkinan salah dalam pelaksanaan bisa diatasi.

\section{c. Pengamatan dan Evaluasi}

Untuk tahap ini tim peneliti melakukan observasi atas penerapan metode Jigsaw di perkuliahan SIM. Observasi yang dilakukan oleh observer dalam penelitian ini adalah observasi tertutup. Observer menyiapkan dan menggunakan lembar observasi untuk mencatat segala hal yang terjadi di perkuliahan SIM pada saat metode Jigsaw digunakan.

\section{d. Refleksi}

Setelah semua tahapan di atas selesai, maka perlu dilakukan refleksi oleh kolaborator dengan kegiatan diantaranya adalah melakukan analisis, penafsir- an, menjelaskan, dan menyimpulkan. Hasil refleksi kolaborator berisikan beberapa rekomendasi untuk peneliti untuk perbaikan proses perkuliahan SIM selanjutnya.

\section{Siklus II}

Berdasarkan hasil temuan yang diperoleh dari refleksi setelah Siklus I akan dikembangkan untuk diuraikan kembali sesuai tahapan perencanaan, pelaksanaan, dan refleksi. Jika setelah Siklus II ditemukan ada peningkatan yang sangat signifikan dan dosen maupun mahasiswa sudah terbiasa dengan metode pembelajaran Jigsaw maka tidak perlu dilanjutkan ke Siklus III. Namun seandainya setelah refleksi Siklus II belum mencapai tujuan penelitian, maka perlu untuk dilanjutkan penelitian ke Siklus III.

\section{Tempat dan Waktu Penelitian}

Penelitian tindakan kelas ini dilakukan di Prodi Sekretari Politeknik Ubaya Surabaya pada Semester Genap Periode Maret-Agustus 2016. Penelitian ini mulai efektif pada saat pertemuan kelima perkuliahan.

\section{Subjek dan Objek Penelitian}

Subjek dari penelitian ini adalah mahasiswa Prodi Sekretari Politeknik Ubaya angkatan 2014 dan 2015 yang berjumlah 16 orang mahasiswa yang mengikuti perkuliahan Sistem Informasi Manajemen. Sementara untuk objek penelitiannya adalah penerapan metode pembelajaran kooperatif Jigsaw untuk meningkatkan pemahaman materi Peranan Informasi dalam Produk dan Jasa.

\section{Teknik Pengumpulan Data}

Penelitian ini memerlukan data yang akurat sehingga bisa memberikan input yang baik bagi proses secara keseluruhan. Peneliti mengumpulkan data dengan menggunakan metode sebagai berikut: observasi, wawancara, dan tes. Untuk mendukung proses pengumpulan data, instrumen yang 
diperlukan adalah: lembar pengamatan, panduan melakukan wawancara, dan handout untuk tes secara tertulis.

\section{Teknik Analisis Data}

Teknik analisis dan pengolahan data yang telah dikumpulkan dari hasil observasi di kelas SIM, wawancara dengan mahasiswa Sekretari 2014 dan 2015, serta tes yang dilakukan di perkuliahan SIM tersebut dianalisis dan diolah dengan teknik pengukuran sebagaimana dijabarkan berikut ini.

\section{Data Hasil Observasi Proses Perkuliahan SIM Subbab Peranan Informasi dalam Produk dan Jasa}

Data hasil observasi proses perkuliahan SIM Subbab Peranan Informasi dalam Produk dan Jasa dengan menggunakan metode Jigsaw, dianalisis dan datanya diolah dengan mengambil nilai rata-rata dengan di bagi dalam 4 kategori: nilai $0,1-1,0=$ Kurang baik; nilai $1,1-2,0=$ Cukup baik; 2,1 - 3,0 = Baik; dan 3,1 - 4,0 = Sangat baik. Hasil observasi dari Siklus 1 dibandingkan dengan hasil observasi Siklus 2 dengan menggunakan nilai persentase. Kemudian hasil persentasenya ditafsirkan apakah sudah menjawab semua pertanyaan yang disebutkan diperumusan masalah, serta apakah sesuai dengan hipotesis tindakan dari PTK ini.

\section{Hasil Penelitian dan Pembahasan}

\section{Analisis Pra-Siklus}

Langkah awal dalam melakukan penelitian ini adalah dengan melakukan kegiatan pra pelaksanaan siklus. Kegiatan tersebut di antaranya adalah mengumpulkan data nama mahasiswa dan nilai mereka dalam beberapa kali ujian sebelumnya. Setelah itu akan diadakan pre test.

Nilai pre-test selanjutnya dijadikan patokan untuk membagi mahasiswa sebelum masuk dalam kelompok Jigsaw.

a. Mahasiswa yang nilainya lebih dari 70; b. Mahasiswa yang nilainya antara 60-70;

c. Mahasiswa yang nilainya kurang dari 60 .

\section{Deskripsi Pelaksanaan Siklus 1}

1. Tahap Perencanaan

Peneliti pada tahap ini mempersiapkan beberapa perangkat seperti rencana topik mata kuliah, soal-soal untuk diskusi dan peralatan yang mendukung diskusi lainnya. Beberapa faktor yang bisa memengaruhi keefektifan metode ini di antaranya adalah faktor mahasiswa, faktor dosen, dan faktor sarana prasarana yang ada di ruang kelas dan kampus.

2. Tahap Kegiatan dan Pelaksanaan

Kegiatan pelaksanaan metode Jigsaw Siklus 1 dimulai dengan rincian aktivitas:

1. Membentuk kelompok;

2. Membagikan topik diskusi dan pertanyaan terkait topik;

3. Mahasiswa menjawab pertanyaan dan memberikan kesimpulan tentang topik diskusi;

4. Dosen memberikan penilaian;

5. Dosen kemudian memberikan tes dengan pertanyaan terkait topik diskusi;

6. Dosen mencatat nilai hasil dari tes Siklus 1.

\section{Observasi (Observation)}

Selain peneliti atau dosen, diperlukan juga seorang kolaborator yang bisa berasal dari rekan sesama dosen di Prodi Sekretari atau di prodi yang lain. Tugasnya adalah melakukan observasi. Observer akan dibekali dengan instrumen berupa lembarlembar pengamatan atas kegiatan dosen dan lembar pengamatan kegiatan mahasiswa

\section{Refleksi}

Refleksi diperlukan agar bisa dievaluasi hal apa saja yang bisa ditingkatkan dalam Siklus 2 nanti. Hasil observasi Siklus 1 di antaranya:

1. Dosen belum maksimal dalam pelaksanaan metode Jigsaw ini, terbukti belum 
aktif dalam membimbing mahasiswa.

2. Mahasiswa juga perlu lebih aktif dalam berdiskusi, karena semua mahasiswa seharusnya punya kesempatan berbicara yang sama dalam forum kecil tersebut.

\section{Deskripsi Pelaksanaan Siklus 2}

1. Tahap Perencanaan

Hampir sama dengan tahap perencanaan di Siklus I, pada tahap Siklus II ini dosen mempersiapkan perangkat diskusi yang terdiri atas rencana perkuliahan, soal tes 3, dan alat pendukung lainnya.

2. Tahap Kegiatan dan Pelaksanaan

Adapun pelaksanaan Siklus 2 sebagai berikut:

a. Kelompok yang sebelumnya sudah terbentuk kembali diminta untuk dukuk bersama.

b. Kelompok melakukan diskusi tentang studi kasus terkait topik Sistem Informasi Manajemen.

c. Dosen melakukan interaksi dengan masing-masing kelompok, memberikan tanggapan, mengoreksi, dan menyempurnakan jika ditemukan kekurangan.

e. Perwakilan mahasiswa dalam kelompok melakukan presentasi mengenai studi kasus dan menjawab beberapa pertanyaan.

f. Dosen memberikan tes Siklus 2 dan mencatat hasil nilainya.

\section{Observasi}

Dengan menggunakan lembar pengamatan untuk dosen dan lembar kegiatan mahasiswa, observer kemudian melakukan observasi mengenai berlangsungnya diskusi di siklus II.

\section{Refleksi}

Hasil dari observasi kemudian digunakan observer dan peneliti untuk melakukan refleksi.

\section{Simpulan dan Saran}

\section{Simpulan}

Berdasarkan pembahasan di atas serta didukung analisis, maka bisa diambil beberapa simpulan sebagai berikut.

1. Sebelum diterapkannya metode Jigsaw, mahasiswa cenderung pasif dalam aktivitas pembelajaran di dalam kelas. Setelah penerapan metode Jigsaw pada Siklus 1, sebanyak 75\% mahasiswa Prodi Sekretari menunjukkan minat untuk berperan aktif dalam diskusi. Pada Siklus 2 penerapan metode Jigsaw, sebanyak 90\% mahasiswa antusias mengikuti jalannya diskusi dalam kelompok. Terjadi peningkatan cukup signifikan sebesar $15 \%$.

2. Setiap selesai siklus pelaksanaan, dosen memberikan tes tertulis maupun lisan kepada mahasiswa. Hasilnya sangat menggembirakan, karena pada Siklus 1 dan 2 mahasiswa yang sebelumnya tidak pernah berani untuk menjawab pertanyaan lisan sebelum penerapan Jigsaw terbukti mulai aktif menjawab pertanyaan yang diajukan.

\section{Saran}

Selanjutnya berdasarkan simpulan tersebut di atas, disarankan hal-hal berikut.

1. Bagi mahasiswa Sekretari yang ingin lebih menguasai materi perkantoran, sebaiknya membiasakan diri dengan belajar menggunakan metode Jigsaw. Karena metode ini bukan hanya bagus untuk aktivitas kelas, namun juga bisa mendukung kegiatan belajar di luar kelas.

2. Bagi dosen yang ingin menerapkan metode Student Centered Learning (SCL), maka metode Jigsaw bisa dipilih untuk itu karena terbukti mampu meningkatkan minat belajar, memotivasi mahasiswa 
terutama jika mahasiswa dalam kelas tergolong pasif dan belum kreatif dalam belajar.

3. Bagi Prodi Sekretari Politeknik Ubaya, hasil penerapan metode ini baik untuk digunakan sebagai bahan dalam diskusi internal prodi. Sehingga bisa menambah pembendaharaan metode pembelajaran yang bisa diterapkan di kelas-kelas lainnya.

\section{Daftar Pustaka}

http://gurupembaharu.com/home/delapan-langkah-metode-jigsaw/ viewed 26 February 2014.

http://mastugino.blogspot.com/2013/06/pembelajaran-model-jigsaw.html viewed 26 February 2014.

http://www.bakharuddin.net/2014 dan 2015/03/penelitian-tindakan-kelas-ptk-langkah. htmlviewed 26 February 2014.

Yudhistira, Dadang. 2012. Menulis Penelitian Tindakan Kelas yang Apik. Jakarta: PT Gramedia Widiasarana Indonesia.

Yamin, Martinis. 2013. Strategi \& Metode dalam Model Pembelajaran. Jakarta: PT Referensi GP Press Group.

Trianto. 2011. Model-Model Pembelajaran Inovatif Berorientasi Konstruktivistik. Jakarta: PT Prestasi Pustaka Publisher.

Riyanto, Yatim. 2009. Paradigma Baru Pembelajaran. Jakarta: PT Kencana Prenada Media Group. 
